The

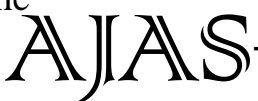

THE ASIAN JOURNAL OF ANIMAL SCIENCE

Volume 13 | Issue 2 | December, 2018 |62-67

DOI : 10.15740/HAS/TAJAS/13.2/62-67

Visit us | www.researchjournal.co.in

- ISSN-0973-4791

RESEARCH ARTICLE.

\title{
Habitat fragmentation due to Tehri dam construction reduces fish species diversity among Bhilangana river, Uttrakhand, India
}

\section{Harpal Singh}

Author for Corresponding -

\section{Harpal Singh}

Department of Zoology, Fish

Reproduction and Conservation Biology Research Lab, H.N.B.

Garhwal University Campus,

Badshahithaul, Tehri Garhwal

(Uttarakhand) India

Emial : dr.harpal83@gmail.com

\begin{abstract}
Rivers of Garhwal Himalaya are becoming increasingly fragmented. The understanding of consequences of the fragmentation on species composition is crucial for conservation of their flora and fauna. In present study, we examined the fish population of river Bhilangana from its lotic site (S-1), its impoundment (S-2) and downstream tailwater (S3) for two consecutive years from May, 2009 to April, 2011. The fishes were collected from the above mentioned sites with the help of local fishermen expert in this occupation. Various Fishing methods such as the Cast nets, Gill nets and Phans and Bour were used for fish collection. The comparative study of fish composition among the fragmented river revealed: 21 fish species belonging to 2 orders, 3 families and 10 genera from of lotic site (S-1), only four species belonging to family Cyprinidae from reservoir site (S-2) and 16 species belonging to 2 order, 3 families and 9 genera from Tailwater (S-3) site. The Snowtrout (Schizothorax spp.) were dominant in fish catch at upstream and downstream sites while Cyprinus carpio which is a non-native species have been dominating in the reservoir site. The Spatial analysis of fish species diversity among the fragmented habitats of the Bhilangana river and comparison with previous study showed negative impacts of fragmentation, which possibly leading to reduced fitness of population and causing a localized extinction.
\end{abstract}

KEY WORDS...... Tehri dam, Habitat fragmentation, Species diversity, Fish assemblage, Gene flow, Gene pool

HOW TO CITE THIS ARTICLE - Singh, Harpal (2018). Habitat fragmentation due to Tehri dam construction reduces fish species diversity among Bhilangana river, Uttrakhand, India. Asian J. Animal Sci., 13(2): 62-67. DOI : 10.15740/HAS/TAJAS/13.2/62-67. Copyright@ 2018:HindAgri-Horticultural Society.

ARTICLE CHRONICLE - Received : 06.09.2018; Revised : 09.11.2018; Accepted : 17.11.2018 